\title{
Effect of Feeding Frequency on Plasma Glucose, Insulin and Glucagon Concentrations in Sheep
}

\author{
Hitoshi Mineo, Takashi Oyamada, Taichi Yasuda, \\ Michio Akiyama, Seiyu Kato and Jun-ichi Ushijima \\ Department of Veterinary Medicine, Rakuno \\ Gakuen University, Ebetsu-shi 069
}

(Recieved June 8, 1989)

\begin{abstract}
The effects of feeding frequency on plasma glucose, insulin and glucagon levels were examined in four female sheep. Feed was given for one, two or three meals but the total amount ( $1500 \mathrm{~g}$ of lucerne pellets and $300 \mathrm{~g}$ of orchard grass hay) given a day was fixed. At the beginning of feeding, plasma glucose was decreased and both insulin and glucagon were increased in all meal patterns. When the frequency of feeding was increased, the changes of plasma glucose and pancreatic hormones were diminished at each feeding time. The mean values of plasma glucose and insulin concentration in a day were increased, whereas glucagon concentration decreased, and, as a result, the $\mathrm{V} / \mathrm{G}$ ratio was decreased by more frequent feeding. In conclusion, changes of feeding frequency, when the same amounts of food a day are given, may affect not only the changes of plasma glucose and pancreatic hormones which immediately occur after feeding, but also the mean value of these nutrients and hormones in a day in sheep.
\end{abstract}

Jpn. J. Zootech. Sci., 61(5) : 411-416, 1990

Key words : feeding frequency, glucose, insulin, glucagon, I/G ratio, sheep

Only small amounts of glucose are absorbed from the gut in ruminants, because most of the dietary carbohydrates are fermented to short chain fatty acids in the reticulorumen. Therefore, gluconeogenesis is important for supplying blood glucose constantly for the demand of ruminants. Pancreatic hormones are extremely important to affect glucose metabolism by controlling glucose production and utilization in the liver and peripheral tissues. UNGER $^{1)}$ pointed out that the molar ratio of insulin and glucagon is one of the indicators of nutrient metabolism status in animals.

There have been many reports about the relationship between the quality of diets and plasma levels of pancreatic hormones in sheep ${ }^{2,33}$. With regards the relationship between feeding pattern and these hormone levels, SuTToN et $a l^{4)}$ reported that more frequent feeding, if the same amount of feed was given a day, decreased the plasma glucagon concentrations, but did not affect the basal value of plasma insulin concentration in lactating cows. However, there is no information about the feeding pattern and pancreatic hormone balance in sheep with a non-lactating stage.

The purpose of this experiment was to clarify the effect of feeding frequency, when the total amount of food whithin a day was constant, on plasma glucose, insulin and glucagon concentrations and the molar ratio of insulin and glucagon (I/G ratio) in sheep. A preliminary account of some of the results has been presented $^{5)}$. 


\section{Materials and Methods}

Animals and diets

Four female sheep weighing $42-45 \mathrm{~kg}$ were used. A few months before the experimentation, these animals had their left carotid artery chronically placed in a loop of skin by surgical operation. They were housed in metabolic cages and water was available continuously. The total amount of their diet was fixed : lucerne pellets $(1500 \mathrm{~g})$ and orchard grass hay $(300 \mathrm{~g})$ per day. Food was generally consumed within one hour after the beginning of feeding in all observations. In Experiment 1 (Expt 1), the total ration was given at 1200 h. In Experiment 2 (Expt 2), the total amount of diet was divided into two equal meals and were given at 1200 and $2400 \mathrm{~h}$. In Experiment 3 (Expt 3), three equal amounts of feed were given at $1200,2400,0400 \mathrm{~h}$. The sheep were accustomed to each feeding condition for at least two weeks before the blood sampling.

Experimental procedure

On the day of each experiment, the catheter was inserted into the exteriorized carotid artery three hours before feeding. The catheter was flushed and filled with sterile solution of $3.8 \%$ tri-sodium citrate. Blood samples $(4 \mathrm{ml})$ were withdrawn from the carotid artery at 0.5-1 hour intervals for a 24-hour period. Blood was transferred into the test tube containing EDTA (Kanto Chemical Co., Inc., Tokyo, Japan) of $1.2 \mathrm{mg} / \mathrm{ml}$ blood and Aprotinin (Hoechst Japan, Ltd., Tokyo, Japan) of $500 \mathrm{KIU} / \mathrm{m} l$ blood.

All experiments were done under lighting conditions.

Analysis

Plasma was separated by centrifugation at $4^{\circ} \mathrm{C}$ and was deproteinized with $10 \%$ tri-chloroacetic acid. Plasma glucose concentrations were determined by the modified glucose-oxidase method of KaBASAKALIAN et $a l^{6)}$. The remaining plasma was stored at $-20^{\circ} \mathrm{C}$ for hormone assay. Plasma insulin concentrations were determined by radioimmunoassay ${ }^{7)}$. Plasma glucagon concentrations were measured by the method of SASAKI et al ${ }^{83}$, using a specific antiserum for pancreatic glucagon (Calbiochem Co., California, U.S.A.).

Results are expressed as mean \pm SE. To compare the diurnal mean levels with each feeding frequency, the mean values of plasma glucose, insulin and glucagon concentrations are calculated from 25 data taken at 1 hour-intervals on the same clock time with each experiment.

DUNCAN's multiple range test was used for statistical analysis after the analysis of variance $(\mathrm{F}$-test).

\section{Results}

Fig. 1 shows the changes of plasma glucose concentrations in three feeding conditions. Plasma glucose levels decreased rapidly after the beginning of the feeding in Expt. 1. In Expt. 2 and 3 , plasma glucose levels began to decrease before the feeding. In all feeding conditions, plasma glucose concentrations increased over the values for a few hours after feeding.

Fig. 2 shows the changes in plasma insulin concentrations in the three experiments. In all feeding experiments, plasma insulin concentrations decreased immediately before feeding and increased after the beginning of the feeding. The response of insulin showed biphasic increasing patterns. The first increment in plasma insulin levels after feeding was almost in a similar degree with the three feeding conditions. The second phase of insulin increment after feeding is shortened by more frequent feeding.

Fig. 3 shows the changes in plasma glucagon concentrations in the three experiments. In Expt. 1, glucagon response to the feeding was not clearly observed, because the pre-feeding value of glucagon in one meal was higher than that in more meals a day. More frequent feeding conditions decreased plasma glucagon levels before feeding. However, the feeding led to a decreased glucagon response, especially in 


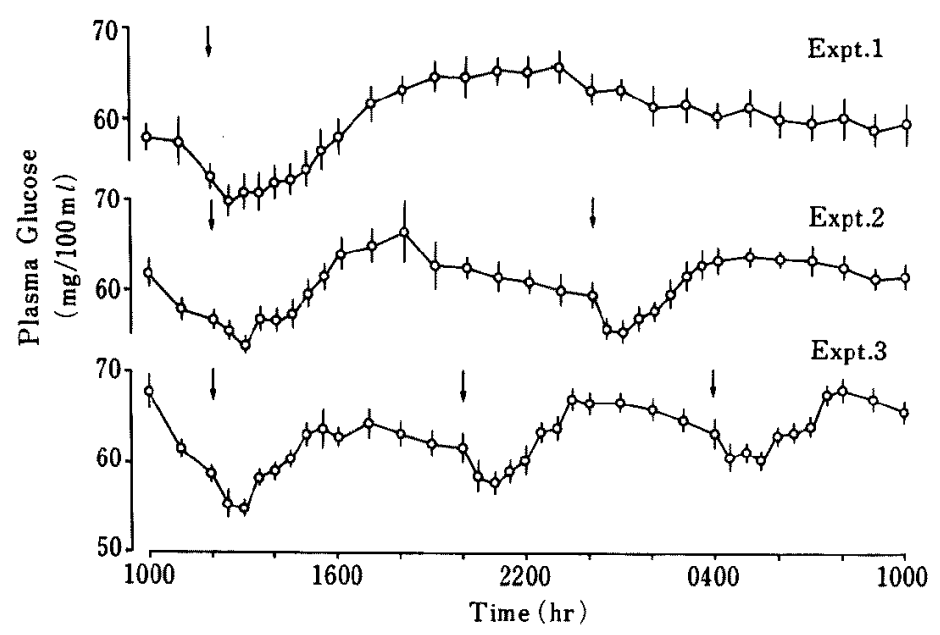

Fig. 1. Changes of plasma glucose concentrations under three feeding conditions in sheep $(N=4)$. Vertical line indicates $S E$ of the mean at each time. (1) mean the presentation of feed.

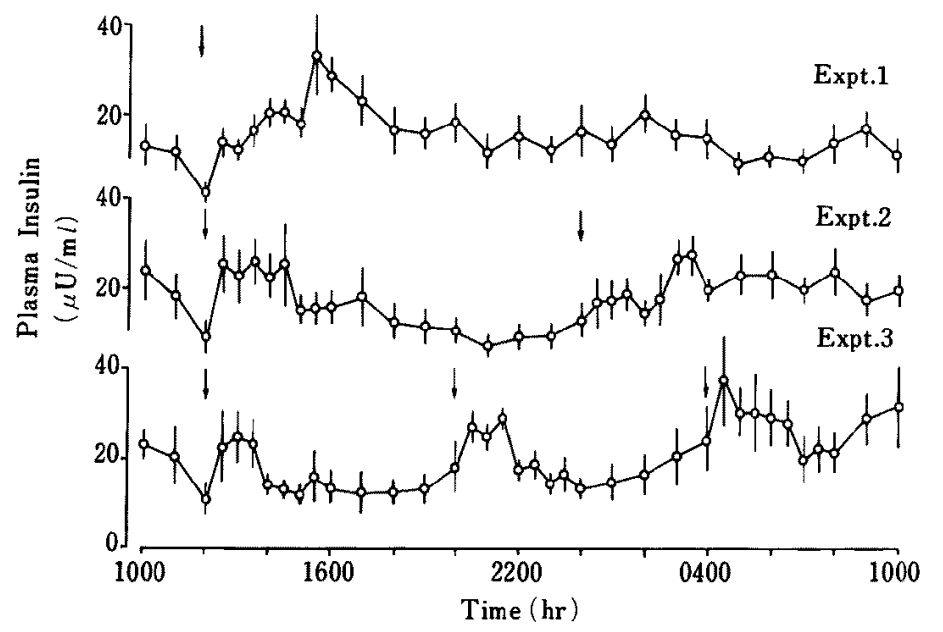

Fig. 2. Changes of plasma insulin concentrations under three feeding conditions in sheep $(N=4)$. Vertical line indicates $S E$ of the mean at each time. $(\downarrow)$ mean the presentation of feed,

the experiments involving three meals a day.

Fig. 4 shows the changes in the $\mathrm{I} / \mathrm{G}$ molar ratio in the three experiments. In all experiments, the $I / G$ rstio increased after feeding, and the profile of the changes in the $I / G$ ratio is similar to the changes of insulin.

Table 1 shows the mean values of plasma. glucose, insulin, glucagon concentrations and the $\mathrm{I} / \mathrm{G}$ ratio for a 24 -hour period in three feeding conditions. The mean levels of plasma glucose concentrations were higher with three meals $(p<0.05)$. The mean values of insulin were higher and that of glucagon levels were lower with three meals a day $(p<0.05)$, and 


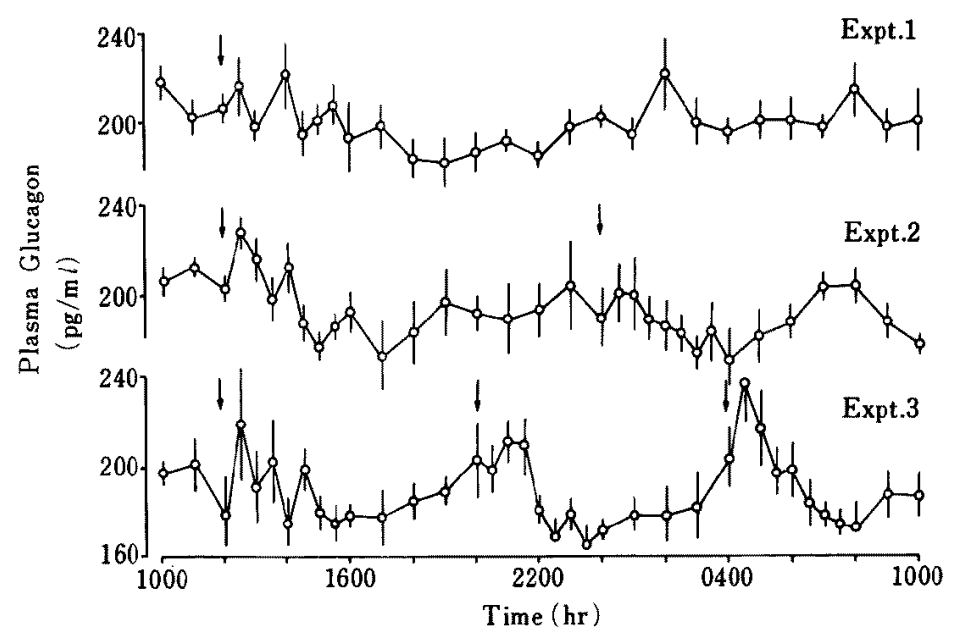

Fig. 3. Changes of plasma glucagon concentrations under three feeding conditions in sheep $(N=4)$. Vertical line indicates $S E$ of the mean at each time. $(\downarrow)$ mean the presentation of feed.

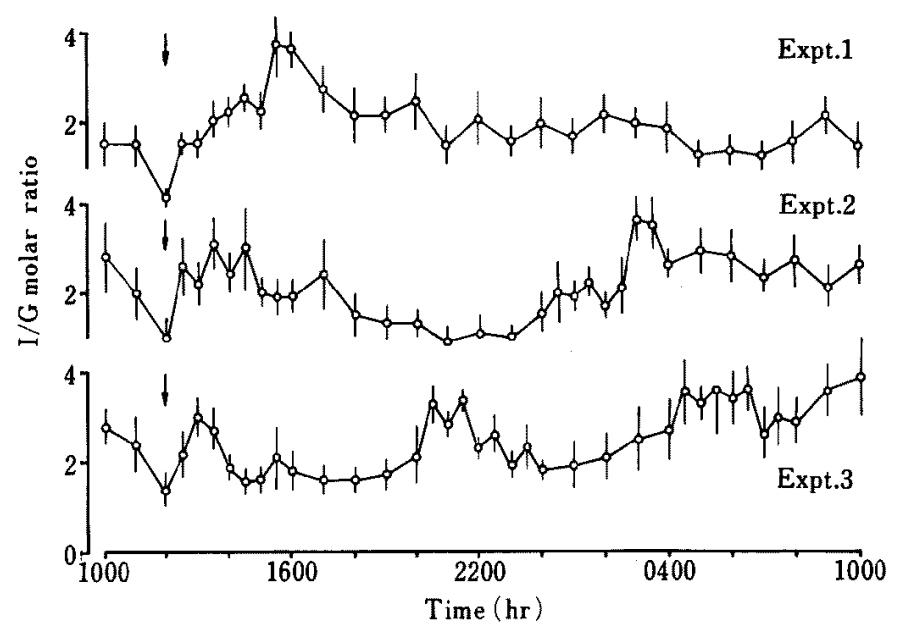

Fig. 4. Changes of Insulin/Glucagon (I/G) molar ratio under three feeding conditions in sheep $(\mathrm{N}=4)$. Vertical line indicates $\mathrm{SE}$ of the mean at each time. $(\downarrow)$ mean the presentation of feed.

therefore, the $I / G$ ratio was significantly higher with more frequent feeding.

\section{Discussion}

Feeding frequency affected the mean values of plasma gucose and pancreatic hormone levels in a day. The mean of glucose concent- rations maintained high levels by more frequent feeding. Blood glucose level is maintained constantly by gluconeogenesis in the liver in ruminants. The increment of glucose in blood is due to an increased glucose production or a decreased utilization of glucose in peripheral tissues. 
Feeding and $\mathrm{I} / \mathrm{G}$ Ratio in Sheep

Table 1. Mean plasma glucose, insulin and glucagon concentrations and I/G ratio for three feeding conditions

\begin{tabular}{lccc}
\hline \multicolumn{1}{c}{ feeds /day } & 1 & 2 & 3 \\
\hline Glucose $(\mathrm{mg} / 100 \mathrm{ml})$ & $60.1 \pm 0.8^{\mathrm{a}}$ & $60.9 \pm 0.6^{\mathrm{a}}$ & $63.0 \pm 0.7^{\mathrm{b}}$ \\
Insulin $(\mu \mathrm{U} / \mathrm{m} l)$ & $14.9 \pm 1.0^{\mathrm{a}}$ & $15.5 \pm 1.1^{\mathrm{a}}$ & $19.2 \pm 1.3^{\mathrm{b}}$ \\
Glucagon $(\mathrm{pg} / \mathrm{ml})$ & $199 \pm 2^{\mathrm{a}}$ & $192 \pm 3^{\mathrm{ab}}$ & $187 \pm 2^{\mathrm{b}}$ \\
I/G ratio & $1.8 \pm 0.1^{\mathrm{a}}$ & $2.0 \pm 0.1^{\mathrm{ab}}$ & $2.4 \pm 0.1^{\mathrm{b}}$ \\
\hline
\end{tabular}

Values are means with $\mathrm{SE}$ of the mean and are calculated from 25 data taken at 1 hour intervals on the same clock time with each experiment.

${ }^{\mathrm{ab}}$ : means in the same row with different superscripts are significantly different $(p<0.05)$ with DUNCAN's multiple range test.

The decrease of glucose uptake by peripheral tissues may not occur, since, in the present result, the $I / G$ ratio is significantly increased by more frequent feeding. The increase of glucose production might be due to the constant supplement of glucose precursor from the rumen (VFA) and from the small intestine (amino acids) by constant digestion and absorption of diets. Changes of pancreatic hormone levels, increase of insulin and decrease of glucagon, were also induced by the constant supplement of energy source from the rumen and small intestine.

In contrast to our data, Sutron et al. ${ }^{47}$ reported that more frequent feeding reduced plasma glucose levels in dairy cows. In addition, basal levels of plasma insulin were not changed, but glucagon levels were decreased by more frequent feeding conditions in their experiments. At present, the reason for these differences is not known. One possibility is that the diet is different between the two experiments. Another possibility is the difference in the condition of animals, with a lactating and non-lactating stage.

BASSETT $^{5)}$ reviewed the control of hormone regulating carbohydrate metabolism in ruminants and pointed out that low $\mathrm{V} / \mathrm{G}$ ratio is needed to maintain gluconeogenesis in ruminants. As carbohydrate supply was increased, the elevated glucose in blood resulted in a high I/G ratio to the balance of metabolism which shifted toward glucose utilization in peripheral tissues.
Plasma glucose concentrations were decreased after the beginning of feeding in all three feeding conditions. A decrease of plasma glucose with feeding was reported in sheep ${ }^{10-12)}$, goats $^{13)}$, and cows ${ }^{11,14,15)}$.

These changes of plasma glucose which occured after feeding might be due to an increase of the utilization of glucose in peripheral tissues, especially of the gastro-intestinal orgsns. High levels of $\mathrm{I} / \mathrm{G}$ ratio immediately after feeding may favour glucose uptake into the peripheral tissues.

The physiological control factors on insulin and glucagon release are not clear in the present experiment. At present, the amount of feed ingested to the animals was related to pancreatic hormone responses, because hormone response was decreased, when the amount of feed in one meal were decreased, or when feeding frequency was increased.

It was reported that pancreatic hormone response to feeding was related to the amount of food ingested ${ }^{10)}$ and to the quality of the $\operatorname{diet}^{2,3}$. Our results suggest that the frequency of feeding, when the same amounts of food are given, changes a hormone balance of insulin and glucagon in non-lactating sheep. Further studies, determination of other metabolites (VFA and amino acids) and hormones are needed to clarify the relationship between the feeding pattern and the metabolism in animals.

\section{References}

1) Unger, R. H., Diabetes, 20: 834-838. 1971. 


\title{
Mineo, Oyamada, Yasuda, AkiYama, Kato and Ushijima
}

2) Trenkle, A.J. Nutr., $100: 1323-1330.1970$.

3) Ostaszewsk1, P. and W. Barej, Ann, Rech. Vet, 10 : 385-387. 1979.

4) Sutton, J.D., I.C. Hart, S.V. Morant, E. Sheller and A.D. Simmonds, Br. J. Nutr., 60 : 265-274, 1988.

5) Oyamada, T., H. Mimeo, T. Yasuda, M. Akiyama, S. Kato and J. UshiJima, Asian-Australasian J. Anim. Sci., $2: 220-221.1989$.

6) Kabasakalian, P., S. Kalliney and A. Westcott, Clin. Chem, 20 : 606-607. 1974.

7) Sasaki, Y. and H. Takahashl, J. Physiol, 306 : 323-335. 1980.

8) Sasakl, Y., H. Takahashi, A. Aso, A. Ohneda and T.E.C. WEEKES, Endocrinology, 111 : 2070-2076. 1982.
9) BassetT, J.M., Digestion and Metabolism in the Ruminants pp 383-398. University of New England Publishing Unit. Sydney, 1975.

10) Bassett, J.M. Aust. J. Biol. Sci., 27 : 167-181. 1974.

11) Evans,E., J.G. BuCnanan-Smith and G.K. MaCleod, J. Anim. Sci., 41 : 1474-1479. 1975.

12) SASAKl, Y., H. Hiratuka and M. Ishida, Can. J. Anim. Sci., 64: 269-270. 1984.

13) De Jong, A., J. Agric. Sci., (Camb.), 96: 643-657. 1981.

14) Hove, K. and A.K. Blom, Acta Endocrinol., 73 : 289-303, 1973.

15) Bines, J.A., I.C. Hart and S.V. Morants, Horm. Metabol. Res., 15 : 330-334. 1983.

\section{ヒツジの血漿グルコース，インスリンおよびグルカゴン \\ 濃度におよぼす採食頻度の影響}

\author{
峯尾 仁・小山田 尚・安田太一・秋山道夫 \\ 加藤清雄・牛島純一 \\ 酪農学園大学獣医学科, 江別市 069
}

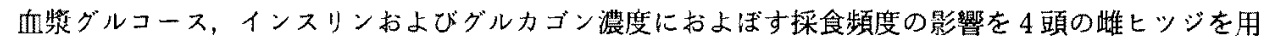
いて検討した． 1 日に与える飼料の総量は一定とし（ルーサンペレット $1500 \mathrm{~g}$ とオーチャードグラス 乾草 $300 \mathrm{~g} ） 1$ 回，2回または 3 回に分けて給与した，採食開始にともなって，血墏グルコースは低下 し，インスリンおよびグルカゴンも変化することが総ての給慨パターンで観察された，採食頻度が增す ことにより，それぞれの採食時に生ずる血墏グルコースおよび膵ホルモンの变動は小さくなった，採食 頻度が多くなることにより，1日の平均血漿グルコースおよびインスリン濃度が上昇し，グルカゴン濃 度が低下したので, その結果, $\mathrm{I} / \mathrm{G}$ 比が上昇した，以上の結果，ヒッジにおいて 1 日の飼料給与量が 同じ場合，採食の頻度が変化することは，採食直後に生ずる血漿グルコースおよび膵ホルモンの変動の みならず，策意素やホルモンの1日の平均レベルにも影響を与えると考元られる，

日畜会報, $61(5) ： 411-416,1990$ 